Науковий вісник Львівського національного університету ветеринарної медицини та біотехнологій імені С.З. Гжицького

Scientific Messenger of Lviv National University of Veterinary Medicine and Biotechnologies

doi:10.15421/nvlvet8119

ISSN 2519-2701 print

ISSN 2518-1327 online

http://nvlvet.com.ua/

УДК 338.24:330. 356.3:665,9(477)

\title{
Економічна ефективністьта інвестиційна привабливість виробництва продукції вермикультури в Україні
}

\author{
В.А. Чемерис, В.І. Душка, В.Л. Максим \\ chemerus64@gmail.com,dushka.vitaliy@gmail.com,volodiamaxym88@gmail.com \\ Львівський наџіональний університет ветеринарної медицини та біотехнологій імені С.З. Гжиџького, \\ вул. Пекарська, 50, Львів, 79010, Україна
}

\begin{abstract}
У статті проведені дослідження економічної ефективностіта інвестииійної привабливості переробки органічних відходів за допомогою вермикультивування на біогумус та іншу супутню продукиію. Відповідно до одержаних результатів аналітично-розрахункових досліджень встановлено, щуо розвиток вермикультури в Україні належить до перспективних напрямів агробізнесу, який не набув широкого поширення та в багатьох регіонах сприймається як інноваиія. Від вермикультивування органічних відходів одержсують три важливі види иінної для сільського господарства продукиї: біогумус, біомаса черв'яка та рідкий субстрат біогумусу (вермичай). Використання якісного біогумусу для удобрення зернових культур, овочів, ягідних та фруктових насаджень сприяє підвищенню їх урожайності на 15-35\%. У світі поширені різноманітні інтенсивні та екстенсивні технології вермикультури, однак в Україні найбільш часто зустрічається організація канальної системи вермикультивування, яка є відносно трудомісткою. У статті досліджується ефективність виробництва продукиії вермикультури на основі технології застосування бортів вертикального типу, яка трунтується на інтенсивному виромуванні каліфорнійських черв'яків у штучно створених умовах із дотриманням мікрокліматичних стандартів в багатоярусних бортах, де засипається спеціально підготовлений субстрат для переробки його на біогумус в приміщеннях закритого типу. Використання інтенсивних способів вермикультивування з вертикальними бортами забезпечує зниження трудомісткості на 50 і більше відсотків порівняно з канальною системою вермибортів. У кожної з доступних для виробника технологій вермикультивування є свої переваги та недоліки. Зокрема використання вертикальних бортів забезпечує високі показники виходу продукиії на одинищю площі, однак характеризується вищою капіталомісткістю одержаної продукиії. За результатами дослідження визначено, що для створення нового високоефективного підприсмства з виробничою потужністю 1200 m біогумусу за рік на основі інтенсивних технологій та без залучення орендованих основних фондів необхідно понад 8 млн грн. стартового капіталу, у тому числі 6,42 млн грн. основного i 1,75 млн грн. оборотного. Інвестовані кошти окупляться за 3,1 роки та забезпечать підприємство чистим прибутком від реалізації продукції за перший рік на суму понад 2 млн грн. Прогнозована дохідність інвестииій становитиме 161\% за 5 років, а чиста приведена вартість проекту досягне 2,77 млн грн. при ставиі дисконту 13,5\%. Рівень рентабельності продажу продукиії перевищить 40\%.

Ключові слова: економічна ефективність, інвестиційна привабливість, продукиї вермикультури.
\end{abstract}

\section{Экономическая эффективностьиинвестиционная привлекательность производства продукции вермикультуры в Украине}

\author{
В.А. Чемерис, В.И. Душка, В.Л. Максим \\ chemerus64@gmail.com, dushka.vitaliy@gmail.com, volodiamaxym88@gmail.com
}

Львовский национальный университет ветеринарной медищины и биотехнологий имени С.3. Гжиџкого, ул. Пекарская, 50, г. Львов, 79010, Украина

В статье проведены исследования экономической эффективностии инвестиционной привлекательности переработки органических отходов с помощью вермикультивирования в биогумус и другую сопутствуюшую продукцию. Согласно полученных результатов аналитически-расчётных исследований установлено, что развитие вермикультуры в Украине отно-

Citation:

Chemerus, V., Dushka, V., Maksym, V. (2017). Economic efficiency and investment attractiveness of vermiculture goods production. Scientific Messenger LNUVMB, 19(81), 107-113. 
сится к перспективным направлением агробизнесу, который не получил широкого распространения и во многих регионах воспринимается как инновация. От вермикультивирования органических отходов получают три важные видь иенной для сельского хозяйства продукции: биогумус, биомасса червя и жидкий субстрат биогумуса (вермичай). Использование качественного биогумуса для удобрения зерновых культур, овощей, ягодных и фруктовых насаждений способствует повышению их урожайности на 15-35\%. В мире распространены различные интенсивные и экстенсивные технологии вермикультуры, однако в Украине наиболее часто встречается организация канальной системь вермикультивирования, которая является относительно трудоёмкой. В статье исследуется эффективность производства продукиии вермикультурь на основе технологии применения бортов вертикального типа, основанной на интенсивном выращцвании калифорнийских червей в искусственно созданных условиях с соблюдением микроклиматических стандартов в многоярусных бортах, где засыпается специально подготовленный субстрат для переработки его в биогумус в помещениях закрытого типа. Использование интенсивных способов вермикультивирования с вертикальными бортами обеспечивает снижение трудоёмкости на 50 и более прочентов по сравнению с канальной системой вермибортов. В каждой из доступных для производителя технологий вермикультивирования есть свои преимущества и недостатки. В частности, использования вертикальньх бортов обеспечивает высокие показатели выхода продукции на единицу площуади, однако более высокой капиталоемкостью полученной продукции. По результатам исследования установлено, что для создания нового высокоэффективного предприятия с производственной мочуностью 1200 m биогумуса в год на основе интенсивных технологий и без привлечения арендованных основных фондов необходимо более 8 млн грн. стартового капитала, в том числе 6420000 грн. основного и 1750000 грн. оборотного. Инвестированные средства окупятся за 3,1 года и обеспечат предприятие чистой прибылью от реализации продукции за первый год на сумму более 2 млн грн. Прогнозируемая доходность инвестиций составит 161\% за 5 лет, а чистая приведённая стоимость проекта достигнет 2770000 грн. при ставке дисконта 13,5\%. Уровень рентабельности продаж продукции превысит $40 \%$.

Ключевые слова: экономическая эффективность, инвестиционная привлекательность, продукции вермикультуры.

\title{
Economic efficiency and investment attractiveness of vermiculture goods production
}

\author{
V. Chemerus, V. Dushka, V. Maksym \\ chemerus64@gmail.com, dushka.vitaliy@gmail.com, volodiamaxym88@gmail.com \\ Stepan Gzhytskyi National University of Veterinary Medicine and Biotechnologies Lviv, \\ Pekarska Str., 50, Lviv, 79010, Ukraine
}

In the article the conducted researches of economic and investment efficiency of organic wastes processing by vermiculture technolology on a biohumus and other concomitant products. In accordance with the results of analytically calculation researches it is set that development of vermiculture in Ukraine belongs to perspective directions of agribusiness which did not get widespread and in many regions perceived as an innovation. From vermiculture organic wastes get three important types of valuable for agricultural producers products: biohumus, biomas of worm and liquid substrat of biohumus (vermitea). The use of high-quality biohumus for the fertilizer of grain-crops, vegetables, berries and fruit planting is instrumental in the increase of their productivity on 15-35\%. Various intensive and extensive vermiculture technologies are widespread in the world, however in Ukraine most often there is organization of the vermiculture channel system which is relatively labour intensive. In the article efficiency of production vermiculture goods is probed on the basis of application technology of vertical type sides, which is based on the intensive growing of the Californian worms in the artificially created terms with the observance of microclimate standards in many-tier sides, where specially geared-up substrat put on for processing on a biohumus in the apartments of the closed type. The use of intensive vermiculture methods with vertical sides provides the decline of labour intensiveness on 50 and more percents by comparison to the channel system of vermi sides. Each of accessible for producers vermiculture technologies have the advantages and failings.

In particular the use of vertical sides provides the high indexes of product output per unit of area, higher capital intensive of products is however characterized. As a result of research certainly, that creation of new high-efficiency enterprise with the production capacity of $1200 \mathrm{t}$ biohumus per year on the basis of intensive technologies and without bringing in of the leased capital assets it is necessary over 8 million UAH of start-up capital, including 6.42 million UAH basic and 1.75 million UAH circulating.

Invested money will be covered during 3.1 year and will provide an enterprise a net income from sale off products for the first year to the amount of over 2 million UAH. Forecasting profitability investments will be $161 \%$ for 5 years, and the net present value of project will attain 2.77 million UAH at the rate of discount 13,5\%. The level of profitability of products sale will exceed $40 \%$.

Key words: economic efficiency, investment attractiveness, vermiculture products.

\section{Вступ}

Переробка органічних відходів відноситься до перспективних видів агробізнесу. Україна володіє значним потенціалом розвитку вермикультури та виробництва органічно чистої сільськогосподарської продукції, який в силу об'єктивних економічносоціальних та правових чинників у значній мірі не реалізований. Переробка органічних відходів на основі впровадження технології вермикультури належить до інноваційних видів підприємницької діяльності, який не набув значного поширення в Україні. Більшість підприємств 3 виробництва продукції вермикультури відносяться до малого бізнесу з річним оборотам капіталу до 2 млн. грн. Одержана продукція від вермикультивування органічних відходів становить значну цінність для розвитку екологічно чистого сільського господарства. Відповідно значної актуальності набуває дослідження економічної ефективності функціонування підприємств, які вибрали даний вид господарської діяльності, а також обгрунтування залучення інвестицій у розвиток вермикультури в Україні. 
Мета дослідження полягає в економічному обгрунтуванні капіталовкладень в організацію виробництва продукції вермикультури. Досягнення мети дослідження грунтується на реалізації поставлених завдань:дослідити технологічні аспекти процесу вермикультивування органічних відходів та виробництва біогумусу; економічно обгрунтувати ефективність переробки органічних відходів на основі впровадження інтенсивних технологій вермикультури; провести інвестиційний аналіз створення спеціалізованого підприємства 3 виробництва вермикомпосту та іншої супутньої продукції.

Аналіз останніх досліджень. Основні проблеми розвитку органічного агровиробництва в Україні висвітлені у працях вітчизняних вчених, серед яких: В. Артиш, В. Гармашов, М. Кобець, О. Рудницька, I. Самаріна, О. Сендецька, В. Сендецький, В. Ткачук, О. Шумейкота інші. Однак не достатньо уваги приділено дослідженню економічної та інвестиційної ефективності виробництва продукції вермикультури, як одного із перспективних видів органічного виробництва.

\section{Матеріал і методи досліджень}

Дослідження економічної ефективностіта інвестиційної привабливості виробництва продукції вермикультури проводилися на основі дедуктивного, монографічного та розрахунково-конструктивного методів. Матеріалами досліджень стали публікації вітчизняних вчених економістів, а також власні спостереження.

\section{Результати та їх обговорення}

Зародження вермикультури як біотехнологічного напряму сільськогосподарської науки розпочалося в 50-ті роки минулого століття у США. В наш час у багатьох країнах світу: Італії, Китаї, Угорщині, Польщі, Японії, США та на Кубі штучне розведення дощових черв'яків поставлено на промислову основу 3 метою утилізації органічних відходів і одержання екологічно безпечного добрива (Samarina, 2012).

Нині розвиток органічного аграрного виробництва на державному рівні в нашій країні регулюється Конституцією України, Земельним кодексом України, Законами України «Про охорону навколишнього природного середовища». Особливого значення набув Закон України «Про виробництво та обіг органічної сільськогосподарської продукції та сировини», який набрав чинності 10 січня 2014 р., згідно якого, органічна продукція ідентифікується як продукція, отримана в результаті сертифікованого виробництва, а виробництво органічної продукції (сировини) визначається як виробнича діяльність фізичних або юридичних осіб (у тому числі з вирощування та переробки), де під час такого виробництва виключається застосування хімічних добрив, пестицидів, генетично модифікованих організмів, консервантів тощо, та на всіх етапах виробництва (вирощування, переробки) застосовуються методи, принципи та правила, визначені Законом для отримання натуральної (екологічно чистої) продукції, а також збереження та відновлення природних ресурсів (Tkachuk, 2015).

Основними видами продукції вермикультури $є$ біогумус, або вермикомпост, біомаса черв'яка та рідкий субстрат біогумусу (вермичай). Для організації виробництва біогумусу використовуються різноманітні види органічних відходів, серед яких найбільш поширеними є гній сільськогосподарських тварин та послід птиці, рослинні відходи (листя, трава, овочі, фрукти), відходи деревообробної промисловості (тирса, опилки), відходи грибних виробництв, пивна дробина, харчові відходи тощо. Найбільш цінною сировиною для організації вермикультури є органічні відходи, які продукуть сільськогосподарські тварини. Від вибору сировини, на основі якої буде вироблятися субстрат, залежить собівартість кінцевої продукції вермикультури. Також вагомим чинником ефективності виробництва є вибір самої технології вермикультивування. Найбільш поширеними 3 них $є$ класична система формування вермиканалів на відкритій місцевості, до якої належать і вермикомпостери промислового типу, а також системи, які формуються у закритих приміщеннях: контейнерна система, реактори безперервної дії бортового типу, вермикультиватори вертикального типу та інші. У статті розглядається використання інтенсивних технологій вермикультивування на основі встановлення вертикальних вермибортів в приміщеннях ангарного типу. Дана технологія відноситься до капіталомістких, оскільки вартість господарського приміщення для організації інтенсивного вермикультувування у структурі основного капіталу часто перевищує 70-75\%. Відповідно оптимальним варіантом може стати оренда придатних для ведення вермикультури господарських об'єктів. Однак, у наших дослідженнях розглядається варіант створення нового спеціалізованого підприємства 3 виробництва продукції вермикультури без залучення орендованих активів.

Виробничий процес у галузі вермикультивування, як і в інших галузях, здійснюється за участі в ньому, крім вермикультури (червоних дощових каліфорнійських черв'яків), робочої сили, основних і матеріальних оборотних засобів виробництва. Їх функціонування реалізується, виходячи 3 конкретних умов відповідної науково обгрунтованої технології, з розробкою технічних умов на продукцію, з організаційно управлінським, фінансовим, обліково-статистичним, патентно-правовим та економічним забезпеченням, 3 використанням економіко-статистичних, економікоматематичних методів моделювання на базі новітніх інформаційних технологій (Sendetska, 2014).

3 метою підвищення родючості грунтів та охорони навколишнього середовища органічні відходи агропромислового комплексу доцільно переробляти методом вермикультивування в «Біогумус», органічне добриво нового покоління, шляхом підбору необхідної кількості, співвідношення компонентів і оптимізації технологічних режимів вермикультивування (Sendetskyi, 2009).

Використання якісного біогумусу для удобрення зернових культур, овочів, ягідних та фруктових насаджень сприяє підвищенню їх урожайності на 15-35\%. На відміну від інших органічних добрив, ефект від 
вермикомпосту одержують уже в поточному виробничому циклі. Зростання урожайності сільськогосподарських культур є одним із основних чинників підвищення економічної ефективності функціонування аграрних підприємств, відповідно якісний біогумус користується усе більшим попитом серед агровиробників.

Технологія виробництва продукції вермикультури на основі застосування бортів вертикального типу грунтується на інтенсивному вирощуванні каліфорнійських черв'яків у штучно створених умовах із дотриманням мікрокліматичних стандартів в багатоярусних бортах, де засипається спеціально підготовлений субстрат для переробки його на біогумус. Загалом з 1 т органічних відходів одержують від 400-500 кг вермикомпосту та близько 100 кг біомаси червяка (табл. 1). Під час періодичного поливу субстрату во- дою з бортів вертикального типу технологічно простіше збирати рідкий вермикомпост, який $є$ також цінним органічним добривом, зокрема для тепличних господарств. Чисельність каліфорнійського черв'яка за рік, при сприятливих умовах утримання збільшується в 30-50 разів. Відповідно для переробки 1 т органічних відходів достатньо однієї маточної групи.

Екстенсивні технології вермикультивування не потребують значних капіталовкладень, однак для створення нового високоефективного підприємства 3 використанням інтенсивних технологій та без залучення орендованих основних фондів 3 виробничою потужністю 1200 т біогумусу за рік необхідно понад 8 млн грн. стартового капіталу, у тому числі 6,42 млн грн. основного і 1,75 млн грн. - оборотного. Структура залученого капіталу наведена на рисунках 1 та 2.

Табличя 1

Основні технологічні показники виробництва продукції вермикультури*

\begin{tabular}{|l|c|}
\hline Обсяг виробництва біогумусу, т & 1200 \\
\hline Обсяг субстрату для черв'яків, т & 2200 \\
\hline Чисельність однієї маточної групи черв'яків, шт, +/- 100 & 2500 \\
\hline $\begin{array}{l}\text { Продуктивність (переробки субстрату в біогумус), у розрахунку на 1 маточну групу черв'яків за рік } \\
\text { розміщену на вермибортах вертикального типу у приміщеннях закритого типу, т }\end{array}$ & 1,65 \\
\hline Необхідна кількість маточних груп черв'яків для реалізації проекту, шт & 1333 \\
\hline Включно з додатковим резервом (+15\%), шт & 1533 \\
\hline Структура затрат субстрату на виробництво продукції вермикультури, \% & 55 \\
\hline на біогумус & 40 \\
\hline біомасу черв'яка & 5 \\
\hline рідкий субстрат біогумусу (вермичай) & 5 \\
\hline Розхід субстрату на 1 т маси черв'яка, т & \\
\hline Плановий обсяг виробництва продукції вермикультури, т & 1200 \\
\hline - біогумусу & 175 \\
\hline - біомаси черв'яка & 0,75 \\
\hline плановий коефіціснт товарності біомаси черв'яка & 131,25 \\
\hline$-\quad$ товарна маса черв'яка & 100 \\
\hline$-\quad$ обсяг збору рідкого субстрату біогумусу, м. куб. & \\
\hline
\end{tabular}

*Джерело: власні дослідження.

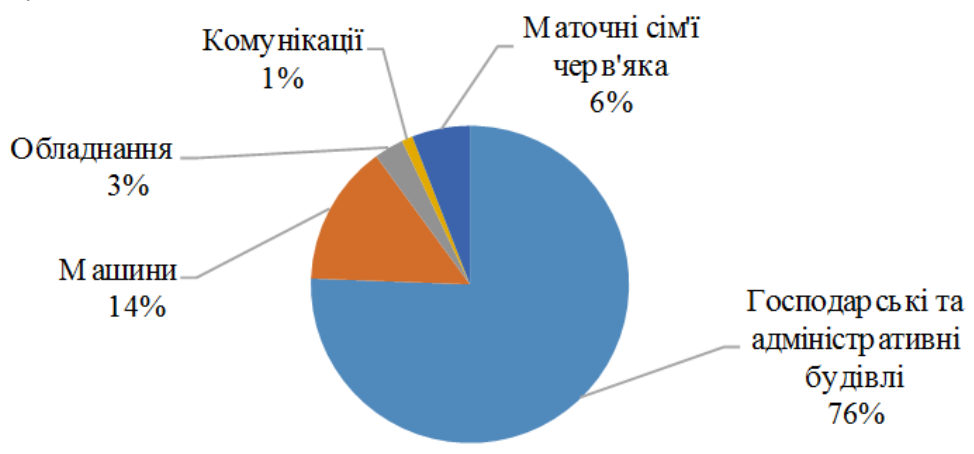

Рис. 1. Структура основного капіталу підприсмства, \%.*

*Джерело: власні дослідження.

Основна частка у структурі основного капіталу припадає на виробничі та адміністративні будівлі. Проте організація вермикультури як додаткового напряму виробництва у вже існуючих підприємствах потребуватиме значно менших інвестицій. Вартість маточного поголів'я та комплектів необхідного обладнання у новоствореному господарстві не перевищує $10 \%$.

Абсолютна більшість технологій виробництва продукції вермикультури, які набули поширення характеризуються значними затратами праці, вартість якої перекладається на собівартість одержаної продукції.
Для екстенсивних технологій оплата праці 3 нарахуваннями часто перевищує $40 \%$. Використання інтенсивних способів вермикультивування 3 вертикальними бортами забезпечує зниження трудомісткості на 50 i більше відсотків порівняно з широко поширеною канальною системою вермибортів. У кожної 3 доступних для виробника технологій вермикультивування $\epsilon$ свої переваги та недоліки. Зокрема, використання вертикальних бортів забезпечує високі показники виходу продукції на одиницю площі, однак характеризується вищою капіталомісткістю одержаної продукції. 
Витрати на оплату праці Упаковка $9 \%$

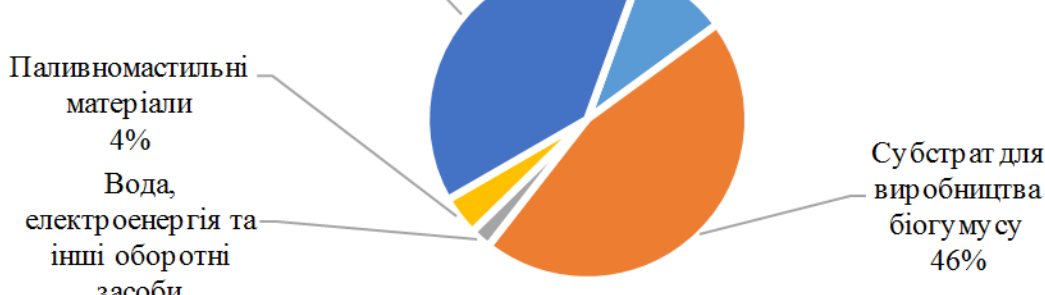

засоби

$2 \%$

*Джерело: власні дослідження.

Табличяя 2

Структура операційних витрат на організацію виробництва продукції вермикультури*

\begin{tabular}{|c|c|c|c|}
\hline Витрати & $\begin{array}{c}\text { Значення показни- } \\
\text { ків, грн. }\end{array}$ & $\begin{array}{c}\text { Структура виробничих } \\
\text { та інших операційних } \\
\text { витрат, \% } \\
\end{array}$ & $\begin{array}{l}\text { Структура опера- } \\
\text { ційних витрат,\% }\end{array}$ \\
\hline \multicolumn{4}{|l|}{ Виробничі витрати } \\
\hline Субстрат для виробництва біогумусу & 800000 & 37,54 & 30,95 \\
\hline Оплата праці & 489600 & 22,98 & 18,94 \\
\hline Соціальне відрахування & 107712 & 5,05 & 4,17 \\
\hline Паливно-мастильні матеріали & 70000 & 3,29 & 2,71 \\
\hline Вода & 22560 & 1,06 & 0,87 \\
\hline Електроенергія & 8775 & 0,41 & 0,34 \\
\hline Амортизація необоротних активів & 632205,8 & 29,67 & 24,46 \\
\hline Всього виробничих витрат & 2130853 & 100 & 82,44 \\
\hline \multicolumn{4}{|l|}{ Витрати від іншої операційної діяльності } \\
\hline загальні корпоративні витрати & 3500 & 0,77 & 0,14 \\
\hline утримання адміністративного персоналу & 235704 & 51,92 & 9,12 \\
\hline $\begin{array}{l}\text { утримання основних засобів загальногосподарсь- } \\
\text { кого використання }\end{array}$ & 10350 & 2,28 & 0,40 \\
\hline витрати на зв'язок & 1350 & 0,30 & 0,05 \\
\hline Витрати на упаковку & 165000 & 36,34 & 6,38 \\
\hline Витрати на реалізацію & 37000 & 8,15 & 1,43 \\
\hline інші операційні витрати & 1100 & 0,24 & 0,04 \\
\hline Разом витрати від іншої операційної діяльності & 454004 & 100,00 & 17,56 \\
\hline Всього операційних витрат & 2584857 & $\mathrm{X}$ & 100 \\
\hline $\begin{array}{l}\text { Операційні витрати у розрахунку на } 1 \text { т реалі- } \\
\text { зованої продукції вермикультури, грн }\end{array}$ & \multicolumn{3}{|c|}{1806} \\
\hline
\end{tabular}

Собівартість продукції вермикультури залежить від дії багатьох технологічних та економічних чинників. До найбільш вагоміших із них відносять вибір власне технології вермикультувування, яка визначає обсяг капіталовкладень на організацію виробництва, кількість залучених працівників для виконання технологічних робіт. Важливим чинником собівартості $\epsilon$ також структура субстрату і вартість його складових.

Відповідно до наведених у таблиці розрахунків, сума операційних витрат у на 1 т реалізованої продукції становить 1806 грн. У структурі операційних витрат понад $80 \%$ становлять виробничі, 3 них більше третини - це вартість субстрату для виробництва біогумусу. На оплату праці з нарахуваннями і амортизація необоротних активів припадає відповідно 28 та $30 \%$ виробничих витрат. Витрати від іншої операційної діяльності на половину складаються 3 вартості утримання адміністративного персоналу. Всього за рік новостворене підприємство понесе до 2,6 млн грн. операційних витрат, які будуть компенсовані виручкою від реалізації продукції вермикультури на суму понад 4,8 млн грн.

У структурі доходу від продажу продукції вермикультури основну частку складає біогумус (рис. 3). На реалізацію черв'яка для кормових цілей припадає близько четверті усіх доходів від вермикультури. Проте, слід зазначити, що реалізація біомаси черв'яка для риболовецьких цілей і розведення дозволить підвищити її частку у структурі доходу.

Слід зауважити, що на ціну біогумусу та вермичаю значною мірою впливають їх якісні показники - сукупність органічних та фізико-хімічних властивостей, які обумовлені дотриманням технологічних стандартів виробництва та якістю компонентів замішаного субстрату. Також важливої уваги слід приділяти стану упаковки та умовам зберігання готової продукції. 


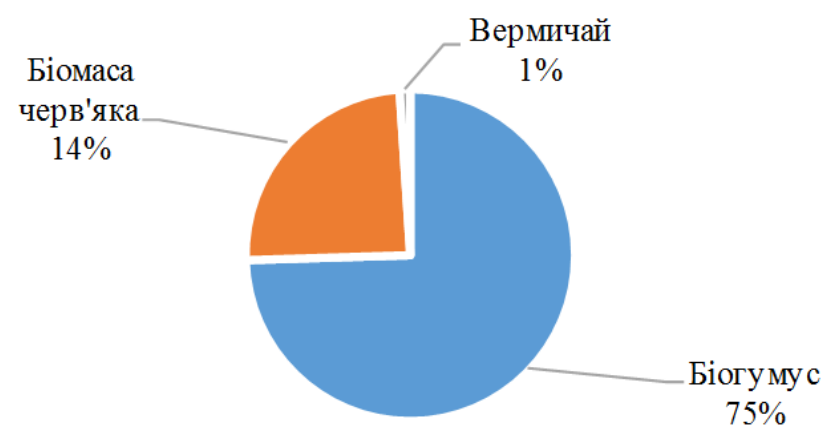

Рис. 3. Структура виручки від реалізації продукції вермикультури, \%.*

*Джерело: власні дослідження.

Табличя 3

Дохід від реалізація продукції вермикультури*

\begin{tabular}{|l|c|c|c|}
\hline \multicolumn{1}{|c|}{ Джерела доходів } & Обсяг реалізації, т & $\begin{array}{c}\text { Ціна за 1 т продукції, } \\
\text { грн }\end{array}$ & $\begin{array}{c}\text { Виручка від реалізації за видами проду- } \\
\text { кції, грн }\end{array}$ \\
\hline Реалізація біогумусу & 1200 & 3000 & 3600000 \\
\hline Біомаса черв'яка & 131,25 & 9000 & 1181250 \\
\hline Вермичай & 100 & 500 & 50000 \\
\hline Разом & 1431,25 & $\mathrm{X}$ & 4831250 \\
\hline
\end{tabular}

*Джерело: власні дослідження.

Табличя 4

Економічна ефективністьта інвестиційна привабливість виробництва продукції вермикультури*

\begin{tabular}{|l|c|}
\hline \multicolumn{1}{|c|}{ Показник } & Значення показників \\
\hline Сума залученого основного капіталу, грн. & 1755480 \\
\hline Сума залученого оборотного капіталу, грн. & 8180110 \\
\hline Разом стартового капіталу, грн. & 5 \\
\hline Термін реалізації проекту, років & 4831250 \\
\hline Виручка від реалізації продукції, грн & 241562,5 \\
\hline Єдиний податок, грн. ** & 4589688 \\
\hline Чиста виручка, грн. & 2130853 \\
\hline Виробничі витрати, грн. & 2458835 \\
\hline Валовий прибуток, грн. & 454004 \\
\hline Витрати від іншої операційної діяльності, грн. & 2004831 \\
\hline Чистий прибуток, грн. & 642556 \\
\hline Амортизація, грн. & 2647387 \\
\hline Чистий грошовий потік (Саsһ-flош), грн. & 94,1 \\
\hline Рентабельність виробництва, \% & 41,5 \\
\hline Рентабельність продажу, \% & 32,4 \\
\hline Рентабельність інвестицій, \% & 3,1 \\
\hline Термін окупності, років & 161,8 \\
\hline Дохідність інвестицій, \% & 10,0 \\
\hline Середньорічний темп зростання капіталу, п.п. & 1,87 \\
\hline Коефіцієнт співвідношення доходів і витрат, од. & 13,5 \\
\hline Розрахована ставка дисконту для проекту, \% & 2774357 \\
\hline Чиста приведена вартість проекту, грн. & 30,19 \\
\hline Внутрішня норма прибутковості проекту,\% & $514682 / 2573413$ \\
\hline $\begin{array}{l}\text { Прогнозована сума податкових платежів до бюджетів усіх рівнів за рік / за 5 } \\
\text { років, грн }\end{array}$ & \\
\hline
\end{tabular}

*Джерело: власні дослідження.

** Сдиний податок (3 група - 5\% від обороту для не платників ПДВ).

Ціна 1 т біогумусу у другому кварталі 2017 р., в 200 грн/кг і вище, з метою їх подальшого розведення залежності від рівня якості, становила 3-4 тис. грн. Більш ціннішою продукцією вермикультури є біомаса черв'яка, вартість якої суттєво різниться відносно визначеного напряму реалізації. Так, оптова ціна продажу маси черв'яка для переробки на кормові цілі не перевищує 10 тис. грн/т. Реалізація дрібних партій для риболовецьких цілей є більш рентабельною, оскільки ціна за 1 кг у середньому на ринку коливається від 150-200 грн. Також, масу черв'яка реалізують іншим підприємствам у вигляді маточних сімей за ціною від для переробки органічних відходів на біогумус. Однак, реалізація біомаси черв'яка за даними напрямами обмежується відносно незначним попитом. Разом 3 біогумусом та біомасою черв'яка підприємства продають рідкий субстрат - вермичай. Основні показники економічної ефективності та інвестиційної привабливості виробництва продукції вермикультури наведені у таблиці 4.

Вартісні показники економічної ефективності та інвестиційної привабливості виробництва продукції 
вермикультури розраховані у цінах 2017 року. Прогнозований чистий прибуток від реалізації продукції складе близько 2 млн грн. за перший рік, що дозволить забезпечити рівень рентабельності виробництва 94,1\%, а рентабельності продажу перевищить 40\%. Рентабельність інвестованого капіталу досягне $32,4 \%$, відповідно період окупності складе близько трьох років. Чиста приведена вартість проекту розрахована за 5 років і становить 2,77 млн грн. при ставці дисконту $13,5 \%$ та внутрішній нормі прибутковості понад $30 \%$ відносить даний проект до числа інвестиційно привабливих. За час реалізації проекту підприємство сплатить понад 2,5 млн. грн. податків до державного та місцевого бюджету, зокрема щорічна сума єдиного податку перевищуватиме 240 тис. грн.

Перспективи подальших досліджень. Показники інвестиційної ефективності для організації виробництва продукції вермикультури повинні бути вищими, якщо виробничі приміщення, а також навантажувальна техніка і транспортні засоби залучатимуться на орендованій основі чи за договорами лізингу. Відповідно розрахунок порівняльної ефективності виробництва продукції вермикультури на орендованих виробничих засобах стане предметом для наших подальших досліджень.

Аграрний сектор України володіє широким спектром можливостей щодо розвитку органічного напряму господарювання, проте розраховувати на успіх можна лише за умови законодавчого і нормативноправового забезпечення, впровадження екологічного менеджменту, належної державної підтримки та суспільного визнання в країні органічного агровиробництва (Shumeiko, 2016).

\section{Висновки}

Вермикультура відноситься до перспективних видів агробізнесу із значним потенціалом розвитку. Основні види продукції вермикультивування формують цінну сировинну базу для виробництва органічно чистої сільськогосподарської продукції. За результатами дослідження встановлено, що для організації переробки 2000 т органічних відходів в новоствореному підприємстві на основі впровадження технології вермикультури необхідно 8,18 млн. грн. інвестицій, у тому числі 6,42 основного та 1,76 оборотного капіталу, які прогнозовано окупляться за 3,1 роки та забезпечать підприємство щорічним чистим прибутком від реалізації продукції вермикультури на суму понад 2 млн грн. Дохідність інвестицій досягне $161 \%$ за 5 років.

\section{Бібліографічні посилання}

Artysh, V. (2010). Rozvytok svitovoho rynku orhanichnoi produktsii. Ekonomika APK. 3, 113-116 (in Ukrainian).

Harmashov, V., Fomichova, O. (2010). Do pytannia orhanichnoho silskohospodarskoho vyrobnytstva v Ukraini. Visnyk ahrarnoi nauky. 7, 11-16 (in Ukrainian).

Zakonu Ukrainy «Pro vyrobnytstvo ta obih orhanichnoi silskohospodarskoi produktsii ta syrovyny» [Elektronnyiresurs]. Rezhymdostupu: http://zakon4.rada.gov.ua/laws/show/425-18 (in Ukrainian).

Kobets, M. (2004). Orhanichne zemlerobstvo v konteksti staloho rozvytku. Proekt «Ahrarna polityka dlia liudskoho rozvytku». Aktualni pytannia ahrarnoi polityky: zb. robit 2003-2004. 11, 106-132 (in Ukrainian).

Rudnytska, O. (2006). Rynok produktsii orhanichnoho zemlerobstva v Ukraini. Ahroinkom. 1, 31-34 (in Ukrainian).

Samarina, I. (2012). Pidzemnyiorach [Elektronnyiresurs]. Rezhymdostupu: www.agro-business.com.ua/ agronomiia-siogodni/1156-pidzemnyi-orach.html (in Ukrainian).

Sendetska, O. (2014). Efektyvnist vyrobnytstva i zastosuvannia orhanichnykh dobryv «biohumus» vyhotovlenykh metodom vermykultyvuvannia. Visnyk TNEU. 1, 164-171 (in Ukrainian).

Sendetskyi, V. (2009). Pererobka orhanichnykh vidkhodiv $\mathrm{u}$ biohumus metodom vermykultyvuvannia. Zbirnyk naukovykh prats NNTs «Instytut zemlerobstva UAAN». 12, 50-55 (in Ukrainian).

Tkachuk, V. (2015). Efektyvnist vyrobnytstva orhanichnoi produktsii u silskohospodarskykh pidpryiemstvakh. Rezhymdostupu: http://www.economy.nayka.com.ua/?op=1\&z=4481 (in Ukrainian).

Shumeiko, O. (2016). Orhanichne ahrovyrobnytstvo Ukrainy: tendentsii rozvytku ta vyklyky instytutsionalnoho zabezpechennia. Visnyk TNEU. 2, 33-42 (in Ukrainian).

Received 12.09.2017

Received in revised form 13.10.2017

Accepted 17.10.2017 